\title{
Biogenic SOA formation through gas-phase oxidation and gas-to-particle partitioning - a comparison between process models of varying complexity
}

\author{
E. Hermansson ${ }^{1,2}$, P. Roldin ${ }^{1,3}$, A. Rusanen ${ }^{3}$, D. Mogensen ${ }^{3}$, N. Kivekäs ${ }^{1,{ }^{*}}$, R. Väänänen ${ }^{3}$, M. Boy ${ }^{3}$, and E. Swietlicki ${ }^{1,2}$ \\ ${ }^{1}$ Division of Nuclear Physics, Lund University, P.O. Box 118, 221 00, Lund, Sweden \\ ${ }^{2}$ Centre for Environmental and Climate Research, Lund University, P.O. Box 118, 221 00, Lund, Sweden \\ ${ }^{3}$ Department of Physics, P.O. Box 64, 00014 University of Helsinki, Helsinki, Finland \\ *now at: Atmospheric Composition, Finnish Meteorological Institute, P.O. Box 503, 00101, Helsinki, Finland
}

Correspondence to: E. Hermansson (emilie.hermansson@ nuclear.lu.se)

Received: 21 February 2014 - Published in Atmos. Chem. Phys. Discuss.: 5 May 2014

Revised: 1 October 2014 - Accepted: 2 October 2014 - Published: 12 November 2014

\begin{abstract}
Biogenic volatile organic compounds (BVOCs) emitted by vegetation play an important role for aerosol mass loadings since the oxidation products of these compounds can take part in the formation and growth of secondary organic aerosols (SOA). The concentrations and properties of BVOCs and their oxidation products in the atmosphere are poorly characterized, which leads to high uncertainties in modeled SOA mass and properties. In this study, the formation of SOA has been modeled along an air-mass trajectory over northern European boreal forest using two aerosol dynamics box models where the prediction of the condensable organics from the gas-phase oxidation of BVOC is handled with schemes of varying complexity. The use of box model simulations along an air-mass trajectory allows us to compare, under atmospheric relevant conditions, different model parameterizations and their effect on SOA formation. The result of the study shows that the modeled mass concentration of SOA is highly dependent on the organic oxidation scheme used to predict oxidation products. A near-explicit treatment of organic gas-phase oxidation (Master Chemical Mechanism version 3.2) was compared to oxidation schemes that use the volatility basis set (VBS) approach. The resulting SOA mass modeled with different VBS schemes varies by a factor of about 7 depending on how the first-generation oxidation products are parameterized and how they subsequently age (e.g., how fast the gas-phase oxidation products react with the $\mathrm{OH}$ radical, how they respond to temperature changes, and if they are allowed to fragment dur-
\end{abstract}

ing the aging process). Since the VBS approach is frequently used in regional and global climate models due to its relatively simple treatment of the oxidation products compared to near-explicit oxidation schemes, a better understanding of the above-mentioned processes is needed. Based on the results of this study, fragmentation should be included in order to obtain a realistic SOA formation. Furthermore, compared to the most commonly used VBS schemes, the near-explicit method produces less - but more oxidized - SOA.

\section{Introduction}

Secondary organic aerosols (SOA), formed through gas-toparticle partitioning in the atmosphere, constitute a large part of the global organic aerosol load (Crippa et al., 2014; Hallquist et al., 2009; Jimenez et al., 2009) and affect the climate by absorbing or scattering radiation and acting as cloud condensation nuclei (CCN) (Scott et al., 2014). Over boreal forests, with little anthropogenic influences, most particles are comprised of organic constituents (O'Dowd et al., 2002; Tunved et al., 2006; Yttri et al., 2011), formed when biogenic volatile organic compounds (BVOCs), such as terpenes, are oxidized to form less volatile compounds. Despite the importance of SOA as a climate forcer, large uncertainties remain about the formation mechanisms and properties.

A lot of effort has been put into gaining better knowledge of how SOA is formed (Hallquist et al., 2009) and 
how it can grow nucleation-mode particles into CCN (Kerminen et al., 2012). There are still large uncertainties remaining in the SOA formation process, mostly due to the vast number of known - but especially unknown - oxidation products of BVOCs. It has therefore been common practice in global model studies to simplify the gas-phase oxidation using only two hypothetical oxidation products with laboratory-constrained equilibrium partitioning coefficients to estimate the formation of SOA (Kroll and Seinfeld, 2008), based on the two-product model developed by Odum et al. (1996). This method does not account for continuous oxidation in the gas- or particle-phase, and atmospheric models that use this method generally underestimate organic aerosol mass (e.g., Heald et al., 2005; Spracklen et al., 2011; Volkamer et al., 2006). To reduce these limitations, Donahue et al. (2006) proposed a volatility basis set (VBS) approach, where the oxidation products are sorted into logarithmically spaced volatility bins, making it possible to represent a wider range of organic compounds in the atmosphere. The gas-phase aging (i.e., the continuous gas-phase oxidation of the products) can be taken into consideration by moving the oxidation products in the volatility space. To account for the reduction in volatility when functional groups are added during oxidation, these schemes typically move the products down one volatility bin per oxidation step (Bergström et al., 2012; Lane et al., 2008). Oxidation might however also lead to fragmentation, and models that only consider functionalization of biogenic compounds tend to overestimate the SOA mass concentration (Lane et al., 2008; Murphy and Pandis, 2009). A two-dimensional volatility basis set can be used to keep track of the oxygen-to-carbon $(\mathrm{O}: \mathrm{C})$ ratio during the aging process (Donahue et al., 2011; Jimenez et al., 2009), making it possible to also include fragmentation. Studies that have included fragmentation indicate that it is an important process to consider (Chen et al., 2013; Murphy et al., 2012; Shrivastava et al., 2013). The above-mentioned approaches are however empirical or semi-empirical and thus rely on experimental studies conducted under environmental conditions that resemble those in the atmosphere; conditions which might change during the SOA formation process and during future climate warming.

Another way to represent SOA formation is to use a gasphase mechanism that explicitly predicts the condensable oxidation products. While this process makes it possible to predict growth under conditions and timescales beyond those conducted in laboratory studies, it is computationally heavy and needs to be simplified in order to be applicable (Hallquist et al., 2009). Additionally; the lack of knowledge of the properties of many oxidation products leads to uncertainties in these explicit schemes. A number of studies have modeled SOA formation in chamber experiments using explicit - or near explicit - gas-phase chemistry (e.g., Camredon et al., 2010; Capouet et al., 2008; Jenkin, 2004; Roldin et al., 2014; Valorso et al., 2011). The discrepancies between the modeled and measured SOA formation in many of these studies indi- cate that there exist knowledge gaps that need to be filled in order to better understand the processes behind SOA formation.

In this study, uncertain parameters regarding the evolution of the biogenic oxidation products are identified using two aerosol dynamics box models coupled to different gas-phase oxidation schemes. The following processes are specifically studied:

1. the volatility distribution and oxygenation distribution of stable products formed in the first oxidation step of $\alpha$-pinene oxidation

2. the gas-phase aging rate of the above-mentioned products with the $\mathrm{OH}$ radical

3. the temperature response of the oxidation products

4. fragmentation reactions during the aging process

The aim is to investigate the implementation of different gasphase oxidation schemes and condensation schemes of various complexities, and what effect they have on the modeled evolution of SOA at atmospheric conditions. SOA formation is modeled along an air-mass trajectory over the northern European boreal forest using two aerosol dynamics box models: an updated version of the Aerosol Dynamics, gasphase CHEMistry and radiative transfer model (ADCHEM) (Roldin et al., 2011a) and MALTE-BOX (Boy et al., 2013), which is the zero-dimensional model version of MALTE (Model to predict new Aerosol formation in the Lower TropospherE) (Boy et al., 2006). Both models are coupled to the near-explicit Master Chemical Mechanism version 3.2 (MCMv3.2) (Jenkin et al., 1997; Saunders et al., 2003) which is used when predicting the oxidation products of the BVOCs (here represented by $\alpha$-pinene). Different VBS approaches, which have all been applied in previous modeling studies, are compared with near-explicit modeling of SOA formation to get an indication of the uncertainties involved and the importance of different processes in the VBS regarding SOA formation.

\section{Method}

For all simulations in this study, the models were implemented along an air-mass trajectory retrieved from the Hybrid Single Particle Lagrangian Integrated Trajectory Model (HYSPLIT) model (Draxler and Rolph, 2013) with meteorological data from the Global Data Assimilation System (GDAS), downloaded from NOAA Air Resource Laboratory Real-time Environmental Application and Display sYstem (READY) (Rolph, 2013), linearly interpolated from $3 \mathrm{~h}$ to $1 \mathrm{~min}$ (the main time step used in the simulations). 


\subsection{Model descriptions}

\subsubsection{ADCHEM}

The two-dimensional trajectory model ADCHEM was primarily developed to be used for urban plume studies in the atmosphere (Roldin et al., 2011b). In order to capture the vertical and horizontal dispersion of urban plumes, ADCHEM solves the atmospheric diffusion equation perpendicular to the air-mass trajectory. However, in this study we will only use ADCHEM as a box model (zero-dimensional). The aerosol dynamics scheme in ADCHEM includes homogeneous nucleation, dry deposition, Brownian coagulation and detailed condensation/evaporation. ADCHEM also contains a radiative transfer model which calculates the spectral actinic flux (for more detailed information about ADCHEM, see Roldin et al., 2011a). Different gas-phase oxidation schemes can be coupled to ADCHEM; for more information about these, and also how the pure-liquid saturation vapor pressures of the condensing species are estimated, see Sect. 2.3. The condensation/evaporation module in ADCHEM can be combined either with the non-equilibrium 2DVBS approach, as described in Roldin et al. (2011a), or with a detailed particle-phase chemistry and kinetic multilayer model (Roldin et al., 2014). The saturation vapor pressures for each particle size bin are corrected with Raoult's law, taking into account the non-ideal interactions between compounds in the organic particle phase (activity coefficients) and the Kelvin effect. In this study, we will treat the SOA as a well-mixed liquid and neglect any heterogeneous chemistry.

\subsubsection{MALTE-BOX}

MALTE-BOX is a zero-dimensional model based on the onedimensional column model MALTE (Boy et al., 2006). The box version is described in Boy et al. (2013) and Wang et al. (2013). The model consists of modules for gas-phase chemical reactions and photochemistry together with aerosol dynamics. In this study, emissions of inorganic trace gases and $\alpha$-pinene are treated as explained in Sect. 2.2.1, while the chemistry and the saturation vapor pressures used are explained in Sect. 2.3.3. The aerosol dynamics in MALTEBOX is solved by UHMA, which is described in detail in Korhonen et al. (2004). The model includes Brownian coagulation, condensation/evaporation, dry deposition and several nucleation schemes; however, only condensation/evaporation was considered in this study. The model uses sectional methods and a Runge-Kutta solver to solve the general dynamic equation for aerosols.

The main difference between UHMA and ADCHEM lies in the various vapor property parameterizations and additional mechanisms for the activity coefficients in the condensation algorithm. The densities of the condensing pure organic compounds in UHMA are estimated based on their

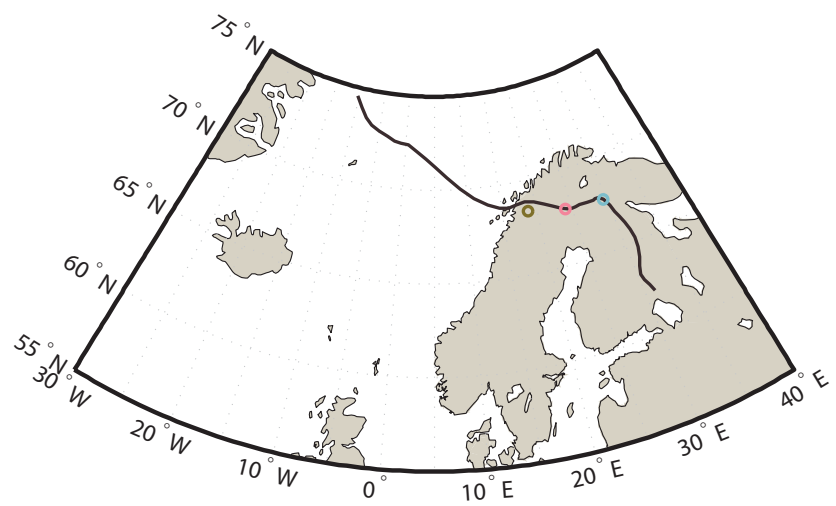

Figure 1. The studied air-mass trajectory retrieved from the HYSPLIT model. The brown, pink and blue circles display the location of the measurement stations Abisko, Pallas and Värriö, respectively.

molecular weights and atomic volumes, taking into consideration the changes in volume due to intramolecular bonding (Girolami, 1994). In ADCHEM, on the other hand, the densities are assumed to be $1400 \mathrm{~kg} \mathrm{~m}^{-3}$ for all condensing organic species (Hallquist et al., 2009). The models also calculate the molecular diffusion coefficients of the vapors differently; ADCHEM uses a method described in Jacobson (2005), whereas MALTE-BOX derives them from Fuller et al. (1966).

\subsection{Model setup}

All model simulations start over the Atlantic Ocean $\left(74^{\circ} 34^{\prime} \mathrm{N}, 10^{\circ} 19^{\prime} \mathrm{W}\right)$ on 28 July $2005,18: 00$ UTC. The air mass then passes close to three remote research stations: first Abisko $\left(68^{\circ} 52^{\prime} \mathrm{N}, 18^{\circ} 30^{\prime} \mathrm{E}, 360 \mathrm{~m}\right.$ a.s.1.) on 31 July 2005 at 03:00 UTC, then Pallas ( $67^{\circ} 56^{\prime} \mathrm{N}, 24^{\circ} 22^{\prime} \mathrm{E}, 565 \mathrm{~m}$ a.s.1.) on 31 July 2005 at 18:00 UTC and finally Värriö $\left(67^{\circ} 45^{\prime} \mathrm{N}\right.$, $29^{\circ} 38^{\prime}$ E, $395 \mathrm{~m}$ a.s.1.) on 2 August 2005 at 00:00 UTC, see Fig. 1. The three stations are located on a west-to-east line roughly $200 \mathrm{~km}$ apart from each other. Description of the stations and the instrumentation can be found in Väänänen et al. (2013). Even though the Pallas station is located on a hilltop, all three stations are considered as ground level sites in this study. Since the boundary layer is assumed to be well-mixed, the air arriving at the stations represents the boundary layer on a larger scale. The specific trajectory was chosen by analyzing hourly HYSPLIT trajectories (Draxler and Rolph, 2013) between the years 2005 and 2007 arriving at Värriö at the altitude of the station. The analysis was limited to trajectories arriving from the Atlantic Ocean and passing over Scandinavia between latitude parallels $67^{\circ} 6^{\prime} \mathrm{N}$ and $69^{\circ} \mathrm{N}$ within $1000 \mathrm{~m}$ above ground level in order to ensure similar source areas and a clear transport route between the stations. Furthermore, the trajectories had to pass over Abisko and Pallas, within $25 \mathrm{~km}$ of the respective station, during its path. This is in line with the general 10-30\% un- 
Table 1. Initial concentrations applied to all model simulations.

\begin{tabular}{llllllll}
\hline Inorganic species & $\mathrm{NO}$ & $\mathrm{NO}_{2}$ & $\mathrm{SO}_{2}$ & $\mathrm{CO}$ & $\mathrm{O}_{3}$ & $\mathrm{H}_{2} \mathrm{O}_{2}$ & $\mathrm{HNO}_{3}$ \\
\hline Concentration [ppb] & 0.1 & 0.2 & 0.2 & 100 & 20 & 0.1 & 0.1 \\
\hline
\end{tabular}

Table 2. Details of the three base case gas-phase schemes investigated in this study.

\begin{tabular}{|c|c|c|c|}
\hline Scenarios & Organic oxidation products & First generation chemistry & $\begin{array}{l}\text { Higher-order-generation } \\
\text { chemistry (aging) }\end{array}$ \\
\hline 1DVBS; Simpson et al. (2012) & $\begin{array}{l}\text { nine products distributed in a } \\
\text { 1DVBS, with temperature de- } \\
\text { pendence explained by } \\
\Delta H_{\text {Eff }}^{\text {Vap }}=30 \mathrm{~kJ} \mathrm{~mol}^{-1} \text {; } \\
\text { Bergströmet al. (2012) }\end{array}$ & 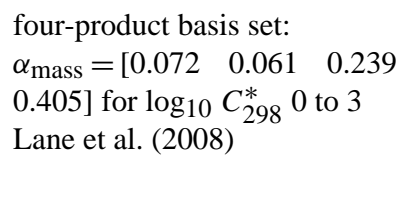 & $\begin{array}{l}\text { aging rate: } \\
k_{\mathrm{OH}}=4 \times 10^{-12} \mathrm{~cm}^{3} \text { molec }^{-1} \mathrm{~s}^{-1} \\
\text { Bergström et al. (2012) }\end{array}$ \\
\hline $\begin{array}{l}\text { MCM; Jenkin et al. (1997); } \\
\text { Saunders et al. (2003) }\end{array}$ & $\begin{array}{l}153 \text { products withvapor pres- } \\
\text { sures estimated from Nan- } \\
\text { noolal et al. }(2008)\end{array}$ & MCMv3.2 & MCMv3.2 \\
\hline
\end{tabular}

certainty of trajectories (Stohl, 1998). The aerosol particle number size distributions at the three stations were analyzed at the times when the trajectories passed them. An airmass that had a low particle number concentration in Abisko which increased between the stations was chosen. Additionally, the trajectory of this air mass had to remain in the boundary layer between the stations with no precipitation along its path. The data from Abisko were used as the initial particle size distribution in the model by using the automatic lognormal-fitting algorithm DO-FIT, version 4.20 (Hussein et al., 2005). Due to the low particle concentration and the origin of the air mass, it was assumed to have a chemical composition of marine aerosol. O'Dowd et al. (2004) measured the physical and chemical properties of aerosols at the research station Mace Head originating from the North Atlantic Ocean during periods of both high and low biological activity in 2002 . The chemical information from their study during periods of high biological activity (here assumed to represent summer conditions) was used to estimate the particle-size-dependent organic fraction. The initial concentrations of the inorganic compounds, not set to zero, are estimated based on average background concentrations and listed in Table 1.

\subsubsection{Emissions}

The inorganic gas emissions $\left(\mathrm{SO}_{2}, \mathrm{NO}_{\mathrm{x}}\right.$ and $\left.\mathrm{CO}\right)$ along the air-mass trajectory were retrieved from the emission database for the year 2005 from EMEP (European Monitoring and Evaluation Programme). The BVOC emissions, assumed to include only $\alpha$-pinene, were estimated using a method described in Tunved et al. (2006), where the flux of $\alpha$-pinene is dependent on the emission potential of coniferous trees, the biomass density of these species along the trajectory (estimated to $950 \mathrm{~g} \mathrm{~m}^{-2}$; Lindfors et al., 1999) and the ambient temperature. Since the simulations are done with zerodimensional models, the $\alpha$-pinene emissions were assumed, as in the study by Tunved et al. (2006), to be confined in a well-mixed boundary layer of a constant height of $1000 \mathrm{~m}$.

\subsection{Description of base case simulations}

In all simulations MCMv3.2 is used to model the gas phase, i.e., the inorganic chemistry and the first oxidation step of $\alpha$-pinene. However, the resulting oxidation products from this step, and their subsequent gas-phase evolution, are modeled with varying complexity. The three schemes used to model the evolution of these condensable organic oxidation products are listed in Table 2 (1DVBS, 2DVBS and MCM) and used throughout this study as base case simulations. The MCM models the organic oxidation products near explicitly with MCMv3.2, while the two VBS approaches, after the first oxidation step of $\alpha$-pinene, distribute the products into groups with different volatility based on chamber measurements. After the products in the VBS simulations have been distributed in their respective VBS space due the gas-phase reactions, their temperature-dependent saturation vapor pressures are calculated. These pressures, no longer bound to the VBS grid, are used in the condensa- 
tion/evaporation module. The 2DVBS simulation is based on the two-dimensional VBS described in Jimenez et al. (2009), and 1DVBS is based on the one-dimensional VBS scheme used in the EMEP model (Bergström et al., 2012). The simulations are described in the sections below and, if not otherwise noted, coupled to ADCHEM.

\subsubsection{DVBS}

The 1DVBS scheme distributes all organic oxidation products between nine volatility classes separated by powers of 10 in saturation vapor concentration, $C^{*}$, ranging from $10^{-5}$ to $10^{3} \mu \mathrm{g} \mathrm{m}^{-3}$. The scheme is based on how SOA are treated in the EMEP chemical transport model (Bergström et al., 2012). The first-generation products from the oxidation of $\alpha$-pinene and ozone are distributed according to a four-product basis set parameterization based on chamber studies (Lane et al., 2008), see Table 2. The products continue to react with the $\mathrm{OH}$ radical with a reaction rate of $4 \times 10^{-12} \mathrm{~cm}^{3}$ molec $^{-1} \mathrm{~s}^{-1}$. At a reference temperature of $298 \mathrm{~K}$, each reaction leads to a reduction in $C^{*}$ by 1 order of magnitude and a $7.5 \%$ increase in mass due to the added oxygen. The Clausius-Clapeyron equation (see Eq. (A2) in Appendix A) is used to calculate the temperature dependence with a constant $\Delta H^{\text {Vap }}$ of $30 \mathrm{~kJ} \mathrm{~mol}^{-1}$. Fragmentation is not considered.

\subsubsection{DVBS}

The 2DVBS base case simulation in this study distributes all organic oxidation products across 12 volatility classes separated by powers of 10 in $C^{*}$, ranging from $10^{-5}$ to $10^{6} \mathrm{\mu g} \mathrm{m}^{-3}$, and 12 discrete $\mathrm{O}: \mathrm{C}$ ratios from 0.1 to 1.2 , in steps of 0.1 . The first-generation products from the oxidation of $\alpha$-pinene by ozone are distributed in the volatility space according to a seven-product basis set parameterization based on chamber studies (Donahue et al., 2009), see Table 2. In order to distribute the products in the second dimension (O : C ratio), Eq. (A1) is used together with the assumption that most first-generation products have the same number of carbon atoms $\left(n_{\mathrm{C}}\right)$ as the parent hydrocarbon, here $\alpha$-pinene with $n_{\mathrm{C}}=10$ (Jimenez et al., 2009). This means that the oxidation of $\alpha$-pinene by ozone is assumed to include no fragmentation. Further oxidation in the gas-phase is based on Jimenez et al. (2009), where the products are assumed to react with the $\mathrm{OH}$ radical with a reaction rate constant of $3 \times 10^{-11} \mathrm{~cm}^{3}$ molec $^{-1} \mathrm{~s}^{-1}$. For more information of functionalization and fragmentation of the oxidation products, see Appendix A.

\subsubsection{MCM}

The MCM base case simulation considers the degradation of $\alpha$-pinene by using the near-explicit gas-phase kinetic mechanism MCMv3.2, which includes - in the case of $\alpha$-pinene degradation - 942 reactions involving 293 organic and 19 inorganic gas-phase compounds. The pure liquid saturation vapor pressures of the 153 most important oxidation products (the non-radicals that contribute to particle growth in the condensation scheme) are estimated using a group contribution method described by Nannoolal et al. (2008). In the first oxidation step, $\alpha$-pinene can react with ozone and the two radicals $\mathrm{OH}$ and $\mathrm{NO}_{3}$. The volatility and $\mathrm{O}: \mathrm{C}$ ratio distribution of the first stable, non-radical generation products formed are compared with the first-generation products derived from chamber experiments (which are used in the VBS simulations). In order to do this, a simulation was done where the first-generation products generated in MCMv3.2 did not continue to react. A low $\mathrm{NO}_{\mathrm{x}}$ environment was assumed with a constant $\mathrm{OH}$ radical concentration of $2 \times 10^{5} \mathrm{~cm}^{-3}$ (about the average concentration over land in the base case simulations) and a starting concentration of $\mathrm{O}_{3}$ of $5 \times 10^{11} \mathrm{~cm}^{-3}$. The starting concentration of $\alpha$-pinene was $8 \times 10^{9} \mathrm{~cm}^{-3}$, and the simulation was run for $72 \mathrm{~h}$ to ensure that all $\alpha$-pinene had been consumed. The result of this simulation is discussed in Sect. 3.2.

\subsection{Processes not investigated in this study}

This study explores different ways to model SOA formation through homogeneous gas-phase reactions and subsequent gas-to-particle partitioning. It is foremost a model comparison study aimed at investigating the impact that different parameterizations regarding homogeneous gas-phase reactions have on modeled particle growth. Other processes that may influence the growth (e.g., emissions, boundary layer meteorology) are treated with relatively simple assumptions. Moreover, SOA formation of course depends on many other complex processes (e.g., nucleation, coagulation, dry deposition, particle-phase chemistry), some of them included in this study but not investigated further. The simulations conducted should therefore not be compared to the measurements presented, but with each other. The measurements are instead shown as an indicator for realistic particle mass concentrations in boreal environments.

\section{Results and discussion}

The influence of the different gas-phase oxidation schemes, described in Sect. 2.3, on the distribution and properties of the $\alpha$-pinene oxidation products is presented in this section. The subsequent effect on the SOA formation along the chosen air-mass trajectory shown in Fig. 1 is compared and discussed. Aside from the three base case scenarios listed in Table 2 and described in Sect. 2.3 above, different sensitivity tests were performed on the 2DVBS to investigate the impact of different assumptions made in the VBS model setup. Details of these simulations are listed in Table 3. In all simulations, if not otherwise mentioned, the gas-phase oxidation schemes were coupled to the aerosol dynamics box model, 
Table 3. Sensitivity test performed on the 2DVBS base case (top row). Changed parameters are described in bold text, all other parameters are kept unchanged.

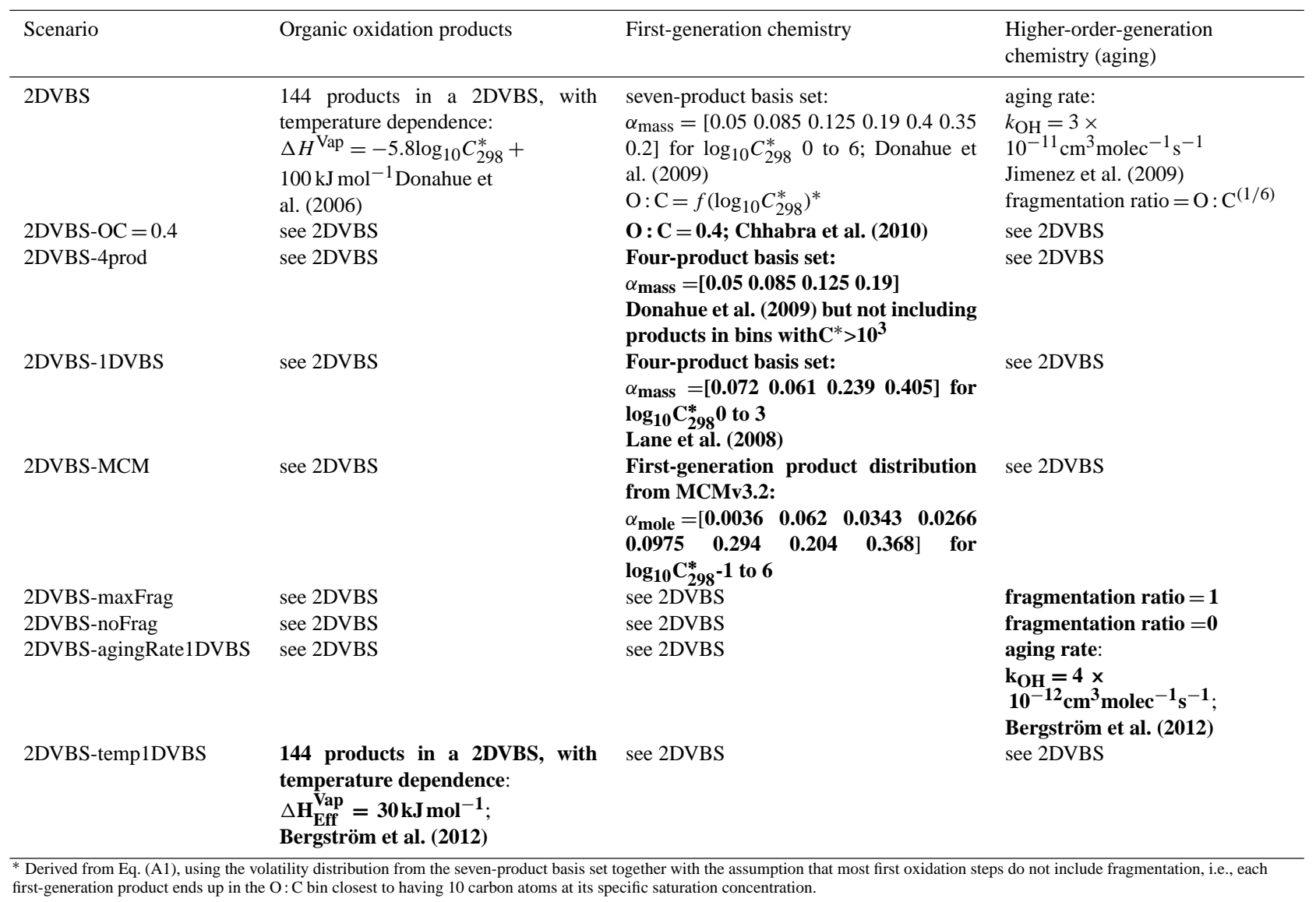

ADCHEM. First however, the condensation modules in the two box models ADCHEM and MALTE-BOX will be compared.

\subsection{Condensation in ADCHEM and MALTE-BOX}

In order to test the sensitivity of the condensation module in ADCHEM, a simulation was done where the aerosol dynamics box model MALTE-BOX, was coupled to MCMv3.2 instead of ADCHEM. Condensation was the only aerosol dynamics process included in both box models for the comparison and the result is shown in Fig. 2. The upper panel shows the volume concentration of SOA along the trajectory, where the dotted blue line is the result from the MCMADCHEM coupling and the dashed pink line the result from the MCMv3.2 being coupled to the MALTE-BOX model. The discrepancy between the modeled mass concentrations is mainly due to the overall lower densities of condensable organics in MALTE-BOX compared to those in ADCHEM. These densities are used when the change of particle mass during condensation (or evaporation) is translated to the corresponding change in particle volume. The solid blue line in the upper panel in Fig. 2 is the result of using the same method as in MALTE-BOX to parameterize the densities of the condensing organic oxidation products in ADCHEM (see Sect. 2.1.2 for more details about the parameterizations). The lower panel in Fig. 2 shows the number size distribution at different times along the trajectory (represented by different colors). The smaller particles seem to grow faster in MALTE-BOX compared to those in ADCHEM, especially during nighttime when the temperature is low. Considering the complexities of both models, they agree fairly well, with a maximum difference in volume concentration of $14 \%$ at $t=129 \mathrm{~h}$ along the trajectory ( 3 August 03:00 UTC), corresponding to a maximum difference in the modeled geometric mean diameter of about $10 \%$.

The pure-liquid saturation vapor pressures of each organic oxidation product, needed to model the condensational growth in near-explicit models, can be estimated using different group contribution methods; both ADCHEM and MALTE-BOX normally use the method described by Nannoolal et al. (2008) (see Sect. 2.3.3). In Fig. 3, SOA formation modeled with ADCHEM using this method is compared to a simulation where ADCHEM instead uses the group contribution method SIMPOL (Pankow and Asher, 2008). 


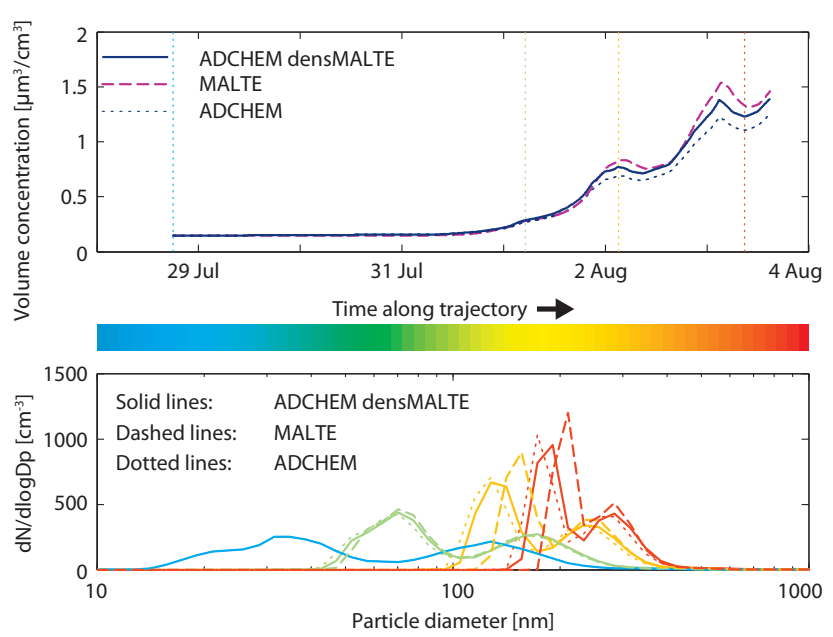

Figure 2. Evolution of particle volume concentration (upper panel) and particle number size distribution (lower panel) modeled with the aerosol dynamics box model MALTE-BOX or ADCHEM (modeled with a constant SOA density of $1400 \mathrm{~kg} \mathrm{~m}^{-3}$ or SOA densities from MALTE-BOX). The color of each size distribution plot represents the size distribution at a specific time along the trajectory, indicated by the corresponding color of the vertical line in the upper panel.

This method causes slower SOA formation since it predicts somewhat higher saturation vapor pressures, illustrating that the estimation of saturation vapor pressures is uncertain and needs to be investigated further.

Moreover, a recent study by Ehn et al. (2014) indicates that the ozonolysis of $\alpha$-pinene might lead to products of extremely low volatility that condense irreversibly to form SOA and thus have the potential to increase the SOA yield significantly. These products are currently not included in the model simulations in this study but we are planning to implement them in future studies.

\subsection{Base case simulations}

The growth of SOA along the chosen trajectory, modeled by the three base case scenarios described in Table 2, is shown in Fig. 4. The figure also includes the calculated mass concentrations from size distribution measurements in Abisko, Pallas and Värriö at the time the air mass passed by. The measurements from Pallas and Värriö are further compared with estimations of particle mass concentrations from two studies, Tunved et al. (2006) and Väänänen et al. (2013), scaled with the size distribution measurement from Abisko. In both of these studies, the mass concentrations are expressed as a function of time the air mass has spent over land. The former study based its estimation on measurements conducted during the growing season (April to September) between 1999 and 2004, and the latter on measurements during the growing season between 2005 and 2007. Aside from the different measurement periods in the studies, Tunved et al. (2006) used

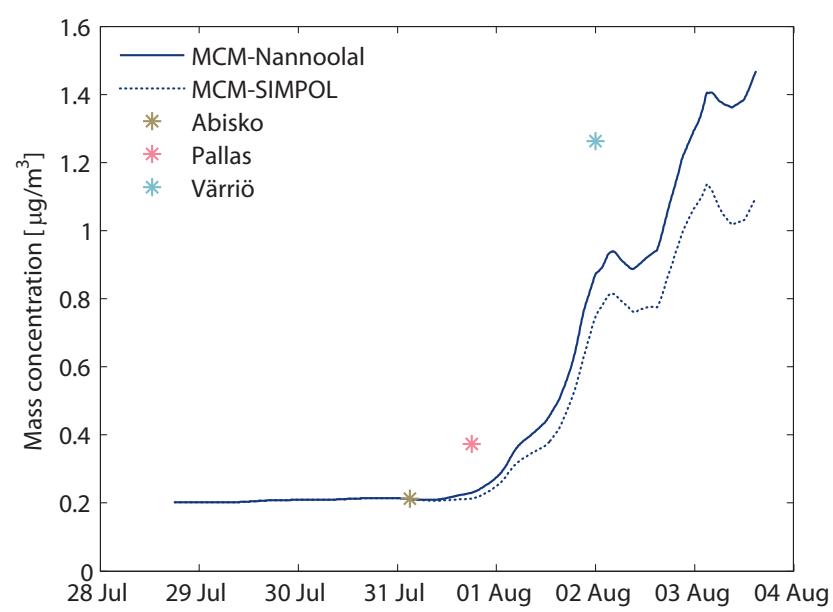

Figure 3. Particle mass concentration along the air-mass trajectory modeled with ADCHEM using different methods of estimating the saturation vapor pressures of the organic oxidation products.

the same expression to estimate the mass concentration both in Pallas and Värriö, while Väänänen et al. (2013) generated two separate estimations: one for Pallas and another for Värriö. This resulted in lower estimated mass concentrations in the study by Tunved et al. (2006) compared to Väänänen et al. (2013), especially in the case of Värriö.

Neither the measurements conducted when the air mass passed the site nor the estimations of the mass concentration from Tunved et al. (2006) and Väänänen et al. (2013) indicate that the particle mass concentration should reach the value it does in the 2DVBS simulation. This simulation also diverges most from the other simulations. In order to understand why the growth of SOA is higher in the 2DVBS, the mass evolution of not only the particle phase, but also that of the gas phase, needs to be studied.

Since a lot of the oxidation products from $\alpha$-pinene exist in significant fractions both in the particle and gas phase at atmospheric conditions, it is informative to look at how they are distributed between the two phases depending on the amount of time they have spent over land. Figure $5 b-d$ show the volatility distribution of the condensable products at the three measurement sites, modeled by the three base case scenarios. Figure 5a shows the distribution of the firstgeneration products, i.e., the first stable, non-radical products from the reaction between $\alpha$-pinene and ozone (in MCM, the first oxidation step also includes reaction with the $\mathrm{OH}$ radical and $\mathrm{NO}_{3}$ ). The darker colors in each bar in Fig. 5b-d illustrate the portion of products in the particle phase; for example, in Abisko almost all products are in the gas phase in all three scenarios. As the air mass moves, $\alpha$-pinene is emitted and its oxidation products are accumulated and oxidized, leading to an increased portion of products partitioning to the particle phase. In Värriö, where the SOA mass concentration is on the order of magnitude of $1 \mu \mathrm{g} \mathrm{m}^{-3}$, compounds with saturation concentration lower than $\sim 10 \mu \mathrm{g} \mathrm{m}^{-3}$ par- 


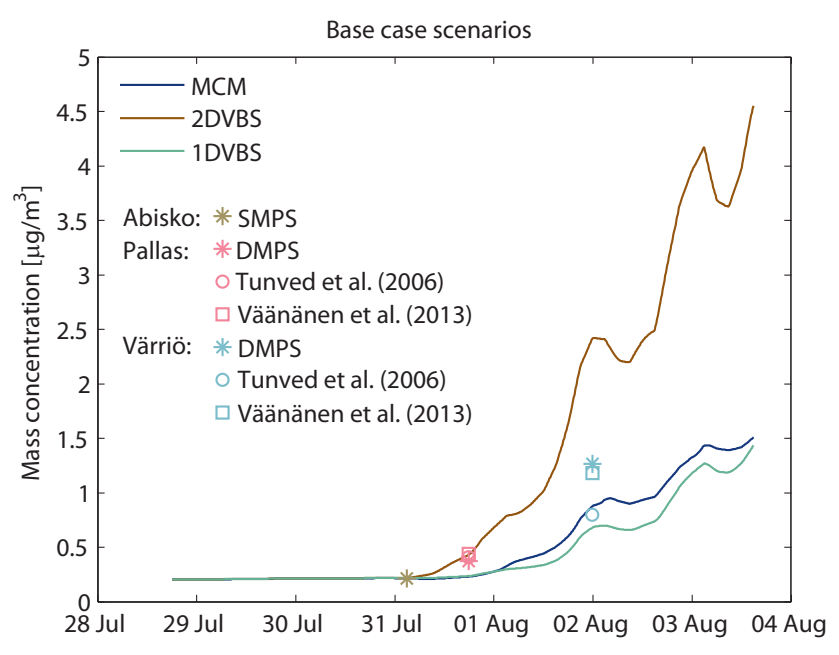

Figure 4. Modeled evolution of particle mass along the studied airmass trajectory. The SMPS (scanning mobility particle sizer) and DMPS (differential mobility particle sizer) data points are the measured size distribution at Abisko, Pallas and Värriö at the time the air mass passed. Also shown are estimated average mass concentrations as functions of the time the air mass spent over land. The rings are based on measurement during the growing season between 1999 and 2004 (Tunved et al., 2006) and the squares are based on measurements between 2005 and 2007 (Väänänen et al., 2013).

tition substantially to the particle phase. The 2DVBS simulation has about $40 \%$ more total mass (gas and particle) in this range in Värriö than the other two base case simulations. The higher mass is partly due to the different firstgeneration chemistry between the model scenarios: compared to the other two base case simulations, the first oxidation step in 2DVBS generates more mass, especially compared to 1DVBS; this will be discussed further in Sect. 3.3. Most of this "extra" mass is located in high-volatility bins and therefore resides in the gas phase; however, if allowed to age, it will increase the particle mass.

Here, it is also evident that while the evolution of particle mass in the MCM and 1DVBS simulations in Fig. 4 show similar patterns, the volatility distribution of their oxidation products does not. The 1DVBS distributes its first-generation products more evenly in the volatility space and - due to the relatively simple parameterization of the aging process - the distribution remains even throughout the simulation. Moreover, the 1DVBS only distributes first-generation products in four bins, products with higher volatilities are (in this scheme) assumed to have no effect on the particle growth and are thus ignored.

Gas-phase oxidation does not necessarily lead to products with lower volatility; the more oxygenated the products are, the higher is the probability that they fragment and form products with lower carbon number (Kroll et al., 2009). Oxidation does however tend to increase the $\mathrm{O}: \mathrm{C}$ ratio of the products (Kroll et al., 2011; Murphy et al., 2011); thus, the
$\mathrm{O}: \mathrm{C}$ ratio can provide valuable information on the amount of aging the compounds have experienced. The $\mathrm{O}: \mathrm{C}$ ratio in regional organic aerosol is about 0.7 (Hallquist et al., 2009).

Figure 6 illustrates both the evolution of $\mathrm{O}: \mathrm{C}$ ratio and volatility of the oxidation products in the SOA formation process, where the grey areas represent the state of the firstgeneration oxidation products (in the gas or particle phase), while the pink ones represent only the particle properties in Pallas (when the air mass has spent $18 \mathrm{~h}$ over land). The mass-weighted average $\mathrm{O}: \mathrm{C}$ ratio of the first-generation products, represented by the stars, are higher in the MCM simulation than in the 2DVBS. Since the MCM volatility is also higher, this implies that fragmentation could play a larger role in the MCM in the first oxidation step, which in turn would mean that more oxidation steps are needed before the products can partition to the particle phase, causing a higher mass-weighted average of the $\mathrm{O}: \mathrm{C}$ ratio of the resulting products in particle phase. The first-generation products in the 1DVBS simulation have about the same $\mathrm{O}: \mathrm{C}$ ratio as the MCM; however, the 1DVBS does not include fragmentation - instead every oxidation step leads to products with lower volatilities, but the aging rate is so slow that almost no aging takes place.

The time evolution of the mass-weighted average SOA properties along the air-mass trajectory starting from Abisko, modeled by the three base case scenarios, are also shown in Fig. 6. In the direction of the arrows, the colors indicate how the particle mass concentration changes during transportation. Except during the first hours, the saturation concentrations in all simulations slightly increase over time since $\alpha$-pinene is continuously emitted along the trajectory. The lower mole fractions of especially the more volatile organic compounds in the particle phase during the first hours probably cause the initial decrease in saturation concentrations (Raoult's law). The MCM and 2DVBS simulations show a stronger diurnal trend in the $\mathrm{O}: \mathrm{C}$ ratio due to temperature variations compared to the 1DVBS. This is probably the result of the simpler aging mechanism in the 1DVBS simulation, e.g., the use of a constant and low enthalpy of vaporization in the 1DVBS.

\subsection{DVBS sensitivity simulations}

The results of the sensitivity tests performed on the 2DVBS simulation are presented in this section. The names and details of these simulations are described in Table 3. The studied parameters are the first-generation chemistry, the aging rate, the enthalpy of vaporization and the role of fragmentation in the 2DVBS. The results of these tests are presented in Fig. $7 \mathrm{a}$ and $\mathrm{b}$.

Figure 7a includes results from simulations where different methods have been used to predict the distribution of firstgeneration products from the oxidation of $\alpha$-pinene. The effect of using the first-generation volatility distribution from the 1DVBS base case in the 2DVBS (2DVBS-1DVBS, green 


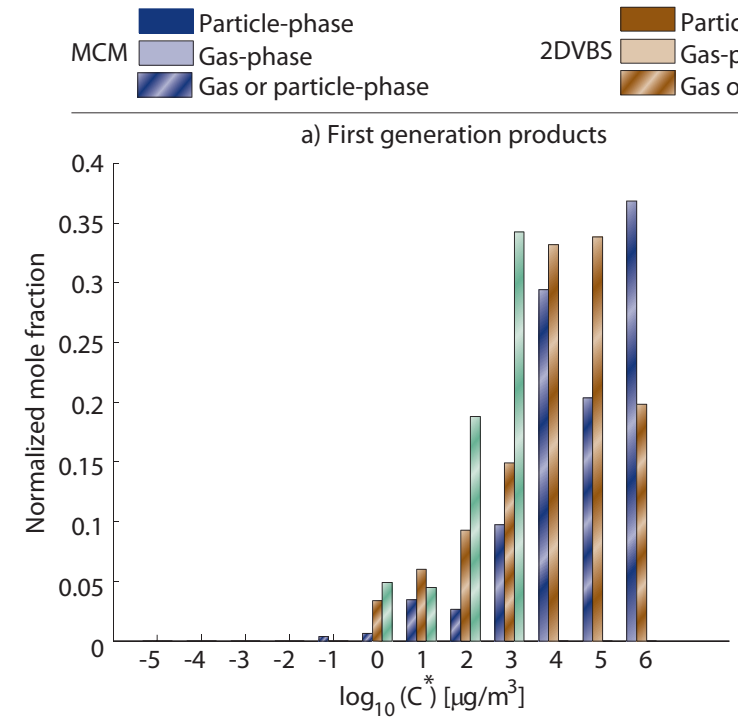

article-phase

as or particle-phase

1DVBS $\square$ Gas-phase

$\square$ Gas or particle-phase
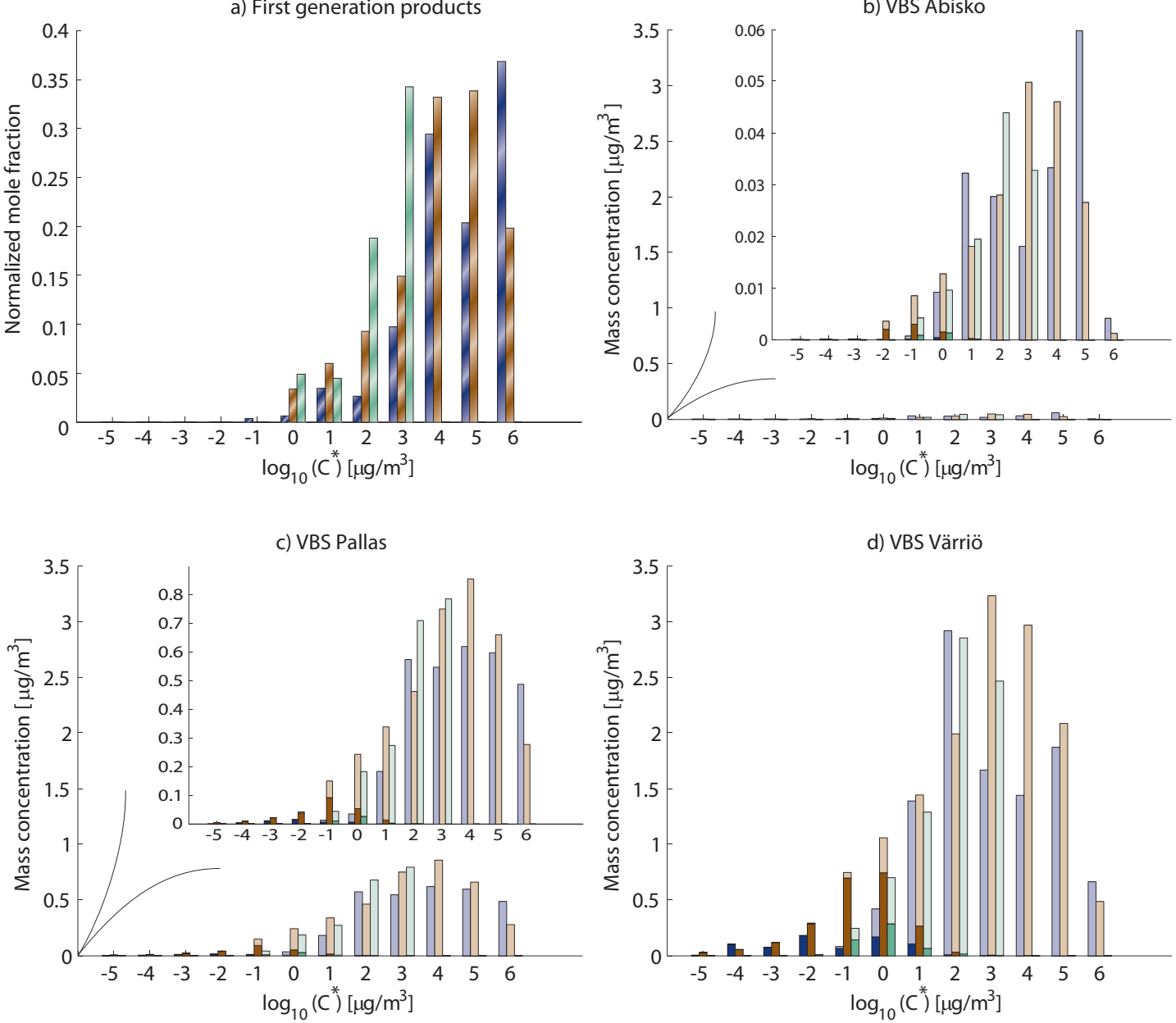

Figure 5. Volatility distribution of the oxidation products in both gas and particle phase from the MCM, 2DVBS and 1DVBS base case simulations. In (a), only products from the first oxidation step are shown, while (b-d) include products from higher-generation oxidation as well. The distributions in (b-d) are at Abisko, Pallas and Värriö, respectively, the dark colors represent the portion of products in the particle phase and the light colors, the portion in the gas phase.

line) is small even though the distributions from the two simulations differ from each other (see Fig. 5a). This does not mean that the volatility distribution of first-generation products have no influence on how the products evolve in the atmosphere. The distribution from the 1DVBS causes the first-generation oxidation products in the 2DVBS-1DVBS to distribute toward lower saturation concentrations, which should lead to a higher SOA growth in the 2DVBS-1DVBS than in the base case 2DVBS scenario. However, due to the relationship between carbon number and volatility in the 2DVBS simulation (Eq. A1) and the assumption that the oxidation of $\alpha$-pinene by ozone do not include fragmentation (i.e., most first-generation products will have carbon number of 9 or 10), the $\mathrm{O}: \mathrm{C}$ ratio of the first-generation products will be higher in 2DVBS-1DVBS than in the base case
2DVBS. This is illustrated in Fig. 8 and explained as follows: since the carbon number of the products are known, the $\mathrm{O}: \mathrm{C}$ distribution of the products can be calculated based on the known volatility distribution of the first-generation products. Figure 8 illustrates how the $\mathrm{O}: \mathrm{C}$ ratio is a function of the volatility when the carbon number is 10 (black line). The first-generation products in the 2DVBS-1DVBS (lower panel, Fig. 8) are distributed towards lower volatilities than the 2DVBS (upper panel, Fig. 8) which explains their higher $\mathrm{O}: \mathrm{C}$ ratios. This will cause a larger fraction of products to fragment in higher-generation oxidation reactions compared to the base case scenario (fragmentation ratio $=\mathrm{O}: \mathrm{C}^{(1 / 6)}$ ), leading to a smaller SOA growth in the 2DVBS-1DVBS. The overall difference between the scenarios is very small. 


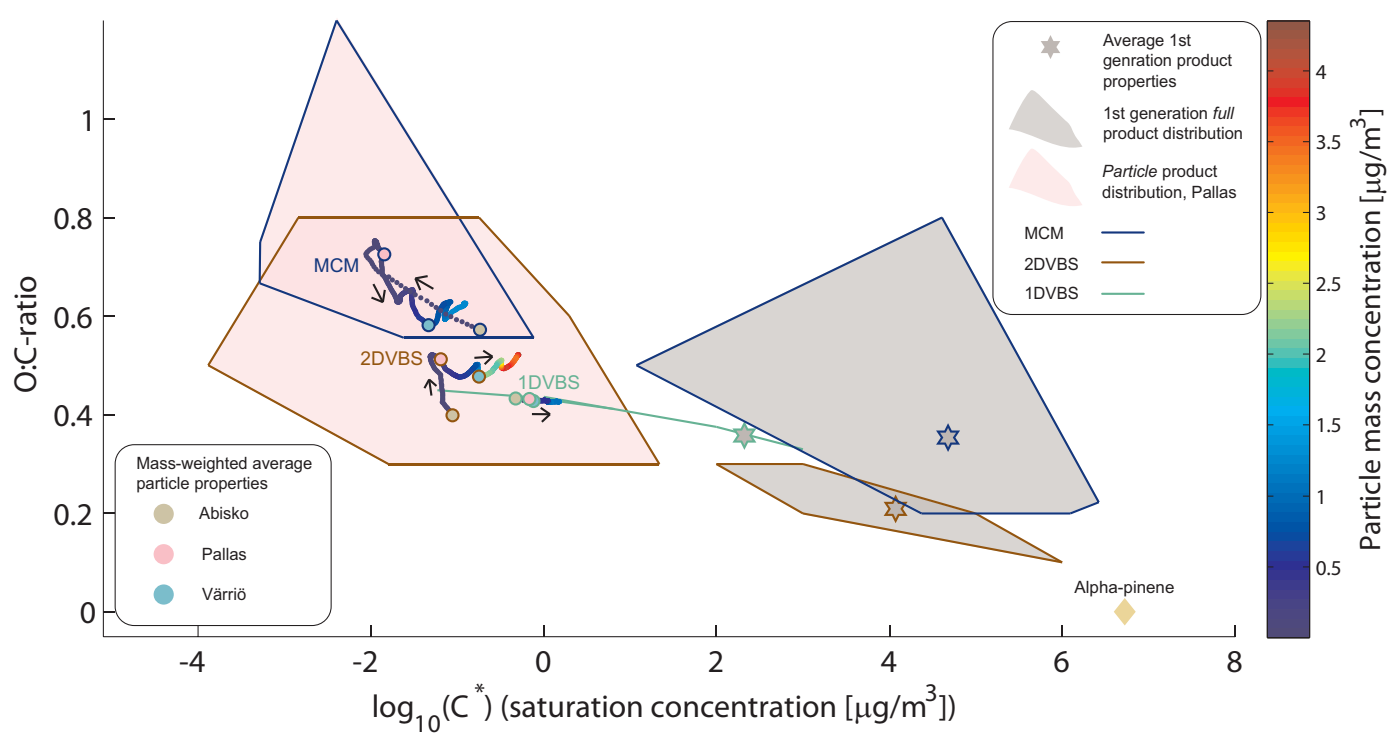

Figure 6. The full (gas or particle) first-generation distributions of the oxidation products in the MCM, 2DVBS and 1DVBS base case simulations are shown as grey areas enclosed with lines, representing each model simulation (MCM - blue, 2DVBS - brown and 1DVBS - green). The grey stars are the corresponding mass-weighted average properties of the first-generation products. The distributions of the products in particle phase in Pallas are shown as pink areas. Also shown, for all three model simulations, are the time evolutions (in the direction of the respective arrows) of the mass-weighted average particle properties and SOA concentration along the air-mass trajectory starting from Abisko (beige circles) and passing Pallas (pink circles) and Värriö (blue circles).

The solid orange line in Fig. 7a shows the resulting growth of SOA when the $\mathrm{O}: \mathrm{C}$ ratio of all first-generation products in the 2DVBS simulation are set to $0.4(2 \mathrm{DVBS}-\mathrm{OC}=0.4)$. This further confirms that higher $\mathrm{O}: \mathrm{C}$ ratio of first-generation products lead to lower SOA mass due to the increased fragmentation. This initial $\mathrm{O}: \mathrm{C}$ ratio is closer to the $\mathrm{O}: \mathrm{C}$ ratio of oxidation products from $\alpha$-pinene ozonolysis measured in chamber studies (Chhabra et al., 2010) and also closer to the corresponding value in the MCM simulation, implying that fragmentation is already important in the first oxidation steps.

The distribution of the first-generation products in the 2DVBS base case scenario, based on Donahue et al. (2009), are constrained by chamber measurements for the products in the volatility bins with saturation concentrations $\left(C^{*}\right)$ between 1 and $1000 \mu \mathrm{g} \mathrm{m}^{-3}$. Based on mass balance calculations, Donahue et al. (2009) concluded that the majority of the mass is unaccounted for and placed the remainder of the mass in bins with higher $C^{*}$ within the VBS. Products in these bins are too volatile to partition to the particle phase; through aging they will however eventually acquire low-enough volatility to condense. The dashed orange line in Fig. 7a (2DVBS-4prod) implies that the aging of these products is an important process since the particle growth is reduced when they are excluded. The distribution of the highvolatility products are however very uncertain. Explicit or near-explicit modeling may provide a more realistic method for predicting these products, keeping in mind that these approaches also include uncertainties (such as the estima- tion of saturation vapor pressures discussed in Sect. 3.1). In the 2DVBS-MCM simulation, the distribution of firstgeneration products in the two-dimensional VBS is predicted using MCMv3.2, while further oxidation is modeled with the 2DVBS. The result of this simulation is represented by the blue line in Fig. 7a (2DVBS-MCM). The reduction in particle growth is caused by the, on average, higher $C^{*}$ and higher $\mathrm{O}: \mathrm{C}$ ratio of the first-generation products modeled by MCMv3.2 compared to the chamber-based mass distribution used in 2DVBS base case scenario. Overall, the different simulations in Fig. 7a vary by about a factor of 3, highlighting the need for more knowledge of the oxidation products, and their distribution, already after the first oxidation step.

In Fig. $7 b$, the result of using different aging parameterizations in the VBS is illustrated. The first-generation products are modeled as in the base case 2DVBS. To test how sensitive the 2DVBS base case scenario is to fragmentation during aging, a simulation without fragmentation (2DVBSnoFrag; dashed black line) and a simulation when all oxidation steps include fragmentation (2DVBS-maxFrag; black line) were conducted. Without fragmentation, the mass of SOA increases to unrealistically high values implying that fragmentation is needed in order to predict realistic values of SOA growth in environments where aging is important for the mass concentration. The effect of the other extreme (fragmentation occurring in each oxidation step) is not as big since compounds in the base case scenario with an $\mathrm{O}: \mathrm{C}$ ratio of 0.5 (about the average $\mathrm{O}: \mathrm{C}$ ratio of SOA in the 2DVBS 
Table 4. Importance of processes that affect particle mass concentration when modeling long-term aging of biogenic SOA in the atmosphere. The uncertainties of the processes are mostly based on results from this study, where processes placed to the left are the most uncertain.

\begin{tabular}{llll} 
& & Uncertainty of parameterization \\
\hline Processes affecting SOA formation & Very uncertain & Less uncertain \\
\hline $\begin{array}{l}\text { First-generation volatility distribution } \\
\text { and oxygenation distributionof } \alpha-\end{array}$ & Important & \\
pinene oxidation products & & Important & \\
OH aging rate constant with the gas- & & Potentially important \\
phase oxidation products & & \\
Temperature response of the oxida- & & \\
tion products & & \\
Fragmentation during aging process & Important & & \\
(if included) & & & \\
\hline
\end{tabular}
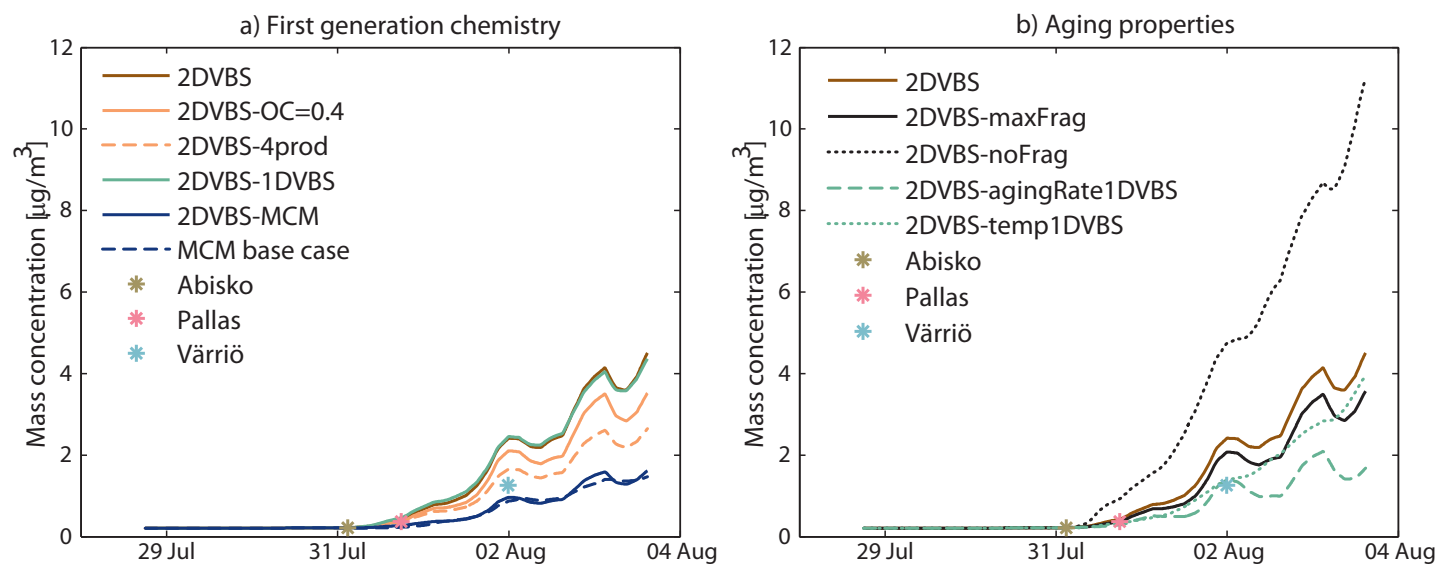

Figure 7. Particle growth along the air-mass trajectory modeled with different versions of 2DVBS (see Table 3 for more details). In (a) different parameterizations of first-generation chemistry are tested and in (b) different parameterizations of gas-phase aging are tested.

base case) already have an $89 \%$ fragmentation probability when oxidized further.

Compared to the 2DVBS base case, products in the 1DVBS simulation react with the $\mathrm{OH}$ radical with a rate constant 1 order of magnitude smaller (based on the aging rate of biogenic SOA in the EMEP model (Bergström et al., 2012)). Using this aging rate that is 1 order of magnitude smaller (2DVBS-agingRate1DVBS; dashed, green line) causes substantial reduction of SOA mass. However, since the products do not age much in this scenario, the average $\mathrm{O}: \mathrm{C}$ ratio of the resulting particles show even lower values $(\sim 0.4)$ compared to the base case $(\sim 0.5)$. Models that only distribute SOA mass based on their volatilities (one-dimensional VBS) do not usually include fragmentation, often forcing them to use unrealistically low aging rates, or exclude aging of biogenic SOA altogether, to keep SOA concentrations at realistic values (Bergström et al., 2012; Murphy and Pandis, 2009).

In the 2DVBS-temp1DVBS simulation (dotted green line in Fig. 7b), the enthalpy of vaporization has been set to a constant value of $30 \mathrm{~kJ} \mathrm{~mole}^{-1}$ (while keeping everything else as in the 2DVBS base case). The result is a reduced temperature response of the particle growth, as well as a somewhat smaller growth; this is due to a distribution of the oxidation products towards higher volatilities compared to the 2DVBS base scenario which uses a $\Delta H^{\text {Vap }}$ that varies with saturation concentration $\left(65-129 \mathrm{~kJ}^{\mathrm{mole}}{ }^{-1}\right)$. Donahue et al. (2006), however, argued that models which include many semi-volatile species should use more realistic values of $\Delta H^{\text {Vap }}$, i.e., values that depend on the volatility of the products.

The assumptions regarding gas-phase aging made in this study have a high impact on SOA formation. Further research is needed in order to make more reliable parameterization, especially when explicit chemistry cannot be used.

\section{Conclusions}

The main conclusions of this study are summarized in Table 4 , in which four processes that have the potential to affect SOA formation are stated: (1) first-generation volatility distribution and oxygenation distribution of $\alpha$-pinene oxidation 


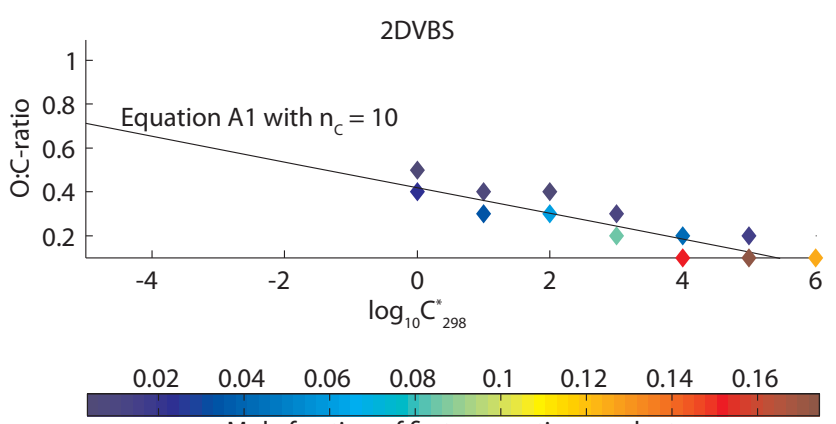

Mole fraction of first generation products

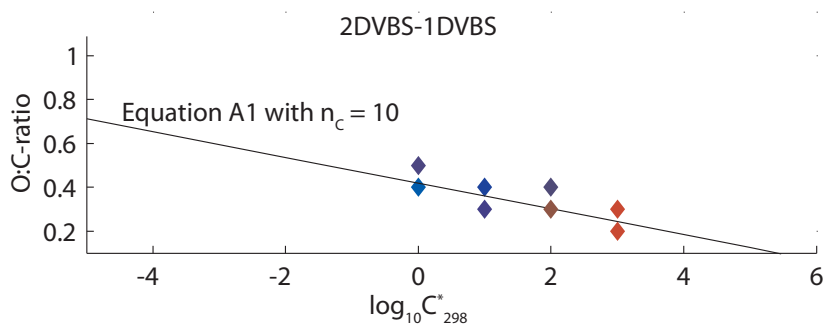

Figure 8. First-generation product distribution in the twodimensional VBS space modeled with the 2DVBS simulation (upper panel) and the 2DVBS-1DVBS simulation (lower panel). The black line shows the linear dependence between the $\mathrm{O}: \mathrm{C}$ ratio and volatility when a carbon number of 10 is assumed.

products, (2) $\mathrm{OH}$ reaction rate constant with the gas-phase oxidation products, (3) temperature response of the oxidation products and (4) the fraction of second- and multi-generation reactions that give fragmentation, assuming that fragmentation is included. The uncertainty and impact these processes have on SOA formation, inferred from the simulations done, are discussed below and summarized in the table:

1. In this study, first-generation oxidation products have been modeled explicitly with MCMv3.2 and compared to two other studies (Bergström et al., 2012; Donahue et al., 2009), where the volatility distributions are parameterized using chamber data. Depending on which was method used, the results differed by about a factor of 3 , implying that the volatility distribution of the first-generation products can have a high impact on SOA formation. The amount of products created through oxidation of BVOCs makes their volatility distribution uncertain, especially for the experimentally derived distribution of the products with high volatility $\left(C^{*}>1000 \mu \mathrm{g} \mathrm{m}^{-3}\right)$ that do not partition to the particle phase at atmospheric conditions, but can nevertheless be important for SOA formation if allowed to oxidize further. The $\mathrm{O}: \mathrm{C}$ ratios of the initial oxidation products are also uncertain parameters. The 2DVBS simulation, based on Jimenez et al. (2009), assumed no fragmentation during the first oxidation step, while some first oxidation steps in the MCM included fragmenta- tion. As a result, the mass-weighted average $\mathrm{O}: \mathrm{C}$ ratio of the products were a little bit higher in simulations using MCMv3.2. The higher $\mathrm{O}: \mathrm{C}$ ratio resulted in a slower particle growth when fragmentation in highergeneration gas-phase reactions were included.

2. The first-generation products are further oxidized by reactions in the gas phase (particle-phase reactions are not considered in this study). In the VBS simulations, it was assumed that the products aged by reacting with the $\mathrm{OH}$ radical with a reaction rate that was independent of where they were located in the VBS space. Based on previous studies, two reaction rate constants were used: $3 \times 10^{-11} \mathrm{~cm}^{3} \mathrm{molec}^{-1} \mathrm{~s}^{-1}$ and $4 \times 10^{-12} \mathrm{~cm}^{3} \mathrm{molec}^{-1} \mathrm{~s}^{-1}$. The lower rate constant resulted in products with unrealistically low $\mathrm{O}: \mathrm{C}$ ratios and substantially reduced the mass concentration of SOA. When the higher reaction rate constant was applied, the aging effect was comparable to the aging in the MCM simulation where the products are predicted near explicitly.

3. Temperature will affect the gas-to-particle partitioning. When a VBS approach is used, individual product information is lost as they are lumped into bins depending on their volatility. In the VBS simulations conducted here, the temperature response was modeled by either letting all bins respond equally to temperature changes or respond accordingly to their saturation concentration. This was controlled by choosing a constant or volatility-dependent enthalpy of vaporization, respectively. In the near-explicit modeling of oxidation products, the temperature response can be modeled in more detail, where each specific product can have their own response. When a volatility-dependent temperature response was used in the VBS, as opposed to letting all products respond equally, the result was in closer agreement with the result from the near-explicit simulation. The importance of the temperature response regarding SOA formation depends on the environment. In a boreal environment, there are many organic semi-volatile compounds which makes the compound-dependent temperature response more important.

4. The results of this study show that fragmentation is important to include during the aging process. It has been shown that fragmentation becomes more important the more oxygenated the compounds are, and a sharp increase in fragmentation from products with $\mathrm{O}: \mathrm{C}$ ratio of 0 up to 0.4 has been observed (Kroll et al., 2009). However, it is very uncertain how to describe the features of fragmentation, especially in the VBS approach. Based on the results from this study, fragmentation should be included to get a realistic SOA formation.

Other uncertainties beyond the scope of this study include particle-phase chemistry and aerosol-phase state. Studies 
have shown that these processes have the potential to affect SOA formation (Chan et al., 2007; Kroll and Seinfeld, 2008; Perraud et al., 2012; Roldin et al., 2014). The diurnal trend, caused by the temperature variation, of the particle mass concentration in the base case scenarios in this study might in part be a result of excluding particle chemistry and assuming equilibrium partitioning. If the condensing gas-phase species are allowed to undergo chemical reactions in the particle phase to form low volatile products, evaporation and re-condensation of these species will be inhibited.
Discrepancies exist between measured and modeled SOA, especially in global model studies, indicating a lack of knowledge about certain processes involving SOA formation. All processes cannot be included in large, global models, but important processes need to be parameterized and included. Box models with process-based representation of aerosol dynamics and gas- and particle-phase chemistry are important tools to understand these processes and explore how to best parameterize them. 


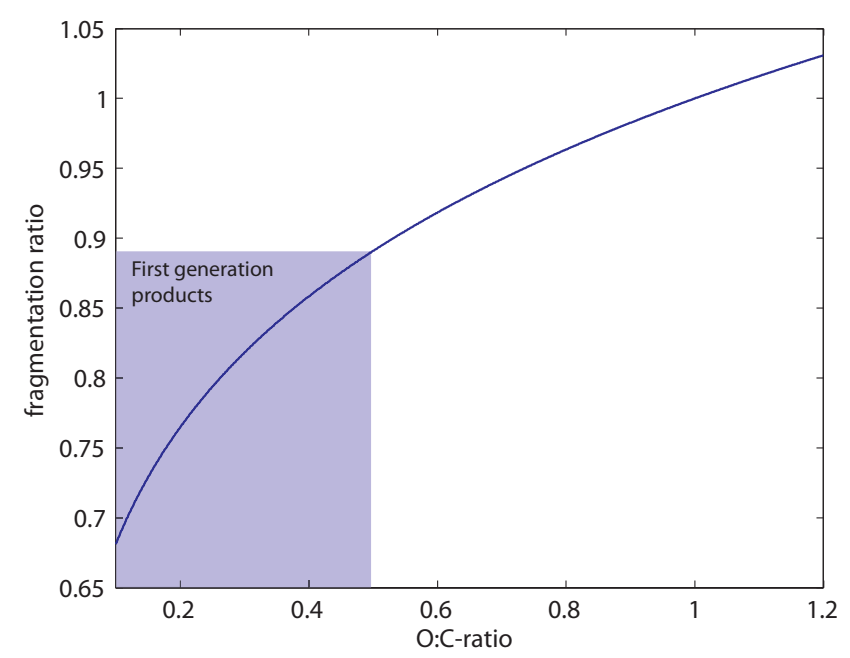

Figure A1. Fraction of products that undergo fragmentation in the 2DVBS scheme as a function of their $\mathrm{O}: \mathrm{C}$ ratio. The shaded area shows the range of $\mathrm{O}: \mathrm{C}$ ratio of the first-generation products in the 2DVBS.

\section{Appendix A: Functionalization and fragmentation in the 2DVBS scheme}

Each oxidation step after the oxidation of $\alpha$-pinene in the 2DVBS includes functionalization where between one and three oxygen atoms are added, causing a reduction in saturation vapor concentration $\left(C^{*}\right)$ and an increase in the $\mathrm{O}: \mathrm{C}$ ratio. The increase in $\mathrm{O}: \mathrm{C}$ ratio depends on the number of carbon atoms $\left(n_{\mathrm{C}}\right)$ in the bin of the reacting compound, which is estimated using a simple empirical three-parameter group contribution relationship between the pure compound saturation concentration at a reference temperature of $298 \mathrm{~K}$ $\left(\log _{10} C_{298}^{*}\right)$ and the number of carbon and oxygen atoms $\left(n_{\mathrm{O}}\right)($ Eq. A1) (Donahue et al., 2011): $\log _{10} C_{298}^{*}=\left(n_{\mathrm{C}}^{0}-n_{\mathrm{C}}\right) b_{\mathrm{C}}-n_{\mathrm{O}} b_{\mathrm{O}}$

where $n_{\mathrm{C}}^{0}=25$ represents the reference point, defined as the number of carbon atoms in an alkane with $C_{298}^{*}=1 \mu \mathrm{g} \mathrm{m}^{-3}$. $b_{\mathrm{C}}=0.475$ is the slope in the linear relationship between $\log _{10} C_{298}^{*}$ and $n_{\mathrm{C}}$, i.e., the effect of increasing the number of carbon atoms by one is a 0.475 decade decrease in saturation concentration. $b_{\mathrm{O}}=1.7$; resulting in a 1.7 decade decrease in saturation concentration of each added oxygen. To account for the temperature dependence of the saturation concentration, the Clausius-Clapeyron equation (Eq. A2) is used:

$C^{*}=C_{298}^{*} \frac{T_{298}}{T} \exp \left(\frac{\Delta H^{\mathrm{Vap}}}{R}\left(\frac{1}{T_{298}}-\frac{1}{T}\right)\right)$,

where $T_{298}$ is the reference temperature and $R$ is the ideal gas constant. $\Delta H^{\mathrm{Vap}}$ is the enthalpy of vaporization assumed to depend on $C_{298}^{*}$ (Donahue et al., 2006) (see Table 2).

After the functionalization step, a fraction $(f)$ of the products formed can fragment into at least two products with lower carbon numbers. This fraction is an uncertain parameter, but, as suggested by Jimenez et al. (2009), is treated as a function of the $\mathrm{O}: \mathrm{C}$ ratio of the products: $f=\mathrm{O}: \mathrm{C}^{(1 / 6)}$. Figure A1 illustrates the fragmentation probability as a function of the $\mathrm{O}: \mathrm{C}$ ratio, where the range of $\mathrm{O}: \mathrm{C}$ ratios of first-generation products in the 2DVBS is represented by the shaded area. As described in Jimenez et al. (2009), the C-C cleavage is assumed to have an equal probability to take place anywhere along the carbon backbone, and the resulting products will have higher volatility than the reactant. Unlike in Jimenez et al. (2009), however, we assume that the fragmentation does not change the $\mathrm{O}: \mathrm{C}$ ratio of the products. 
Acknowledgements. This work was carried out with the support by Nordic Center of Excellence program (CRAICC - CryosphereAtmosphere Interactions in a Changing Arctic Climate), the EU FP7 projects ACTRIS (Aerosols, Clouds, and Trace gases Research Infra Structure Network) and the European Commission Seventh Framework Programme (FP7) in the project PEGASOS (PanEuropean Gas-AeroSOl-climate interaction Study), the Swedish Strategic Research Program MERGE, Modeling the Regional and Global Earth System, and the Lund Centre for studies of Carbon Cycle and Climate Interaction - LUCCI. We also gratefully acknowledge the support of the Swedish Research Council and the Helsinki University Centre for Environment (HENVI), Academy of Finland Centre of Excellence program (project no. 1118615).

The authors would like to thank Almut Arneth at Karlsruhe Institute of Technology for the size distribution measurements at Abisko, Heikki Lihavainen at the Finnish Meteorological Institute for the measurement at Pallas and Markku Kulmala and Pasi Aalto at University of Helsinki for the measurement at Värriö.

Edited by: S. M. Noe

\section{References}

Bergström, R., Denier van der Gon, H. A. C., Prévôt, A. S. H., Yttri, K. E., and Simpson, D.: Modelling of organic aerosols over Europe (2002-2007) using a volatility basis set (VBS) framework: application of different assumptions regarding the formation of secondary organic aerosol, Atmos. Chem. Phys., 12, 8499-8527, doi:10.5194/acp-12-8499-2012, 2012.

Boy, M., Hellmuth, O., Korhonen, H., Nilsson, E. D., ReVelle, D., Turnipseed, A., Arnold, F., and Kulmala, M.: MALTE - model to predict new aerosol formation in the lower troposphere, Atmos. Chem. Phys., 6, 4499-4517, doi:10.5194/acp-6-4499-2006, 2006.

Boy, M., Mogensen, D., Smolander, S., Zhou, L., Nieminen, T., Paasonen, P., Plass-Dülmer, C., Sipilä, M., Petäjä, T., Mauldin, L., Berresheim, H., and Kulmala, M.: Oxidation of $\mathrm{SO}_{2}$ by stabilized Criegee intermediate $(\mathrm{sCI})$ radicals as a crucial source for atmospheric sulfuric acid concentrations, Atmos. Chem. Phys., 13, 3865-3879, doi:10.5194/acp-13-3865-2013, 2013.

Camredon, M., Hamilton, J. F., Alam, M. S., Wyche, K. P., Carr, T., White, I. R., Monks, P. S., Rickard, A. R., and Bloss, W. J.: Distribution of gaseous and particulate organic composition during dark $\alpha$-pinene ozonolysis, Atmos. Chem. Phys., 10, 2893-2917, doi:10.5194/acp-10-2893-2010, 2010

Capouet, M., Müller, J.-F., Ceulemans, K., Compernolle, S., Vereecken, L., and Peeters, J.: Modeling aerosol formation in alpha-pinene photo-oxidation experiments, J. Geophys. Res., 113, D02308, doi:10.1029/2007JD008995, 2008.

Chan, A. W. H., Kroll, J. H., Ng, N. L., and Seinfeld, J. H.: Kinetic modeling of secondary organic aerosol formation: effects of particle- and gas-phase reactions of semivolatile products, Atmos. Chem. Phys., 7, 4135-4147, doi:10.5194/acp-7-4135-2007, 2007.

Chen, S., Brune, W. H., Lambe, A. T., Davidovits, P., and Onasch, T. B.: Modeling organic aerosol from the oxidation of $\alpha$-pinene in a Potential Aerosol Mass (PAM) chamber, Atmos. Chem. Phys., 13, 5017-5031, doi:10.5194/acp-13-5017-2013, 2013.
Chhabra, P. S., Flagan, R. C., and Seinfeld, J. H.: Elemental analysis of chamber organic aerosol using an aerodyne high-resolution aerosol mass spectrometer, Atmos. Chem. Phys., 10, 4111-4131, doi:10.5194/acp-10-4111-2010, 2010.

Crippa, M., Canonaco, F., Lanz, V. A., Äijälä, M., Allan, J. D., Carbone, S., Capes, G., Ceburnis, D., Dall'Osto, M., Day, D. A., DeCarlo, P. F., Ehn, M., Eriksson, A., Freney, E., Hildebrandt Ruiz, L., Hillamo, R., Jimenez, J. L., Junninen, H., Kiendler-Scharr, A., Kortelainen, A.-M., Kulmala, M., Laaksonen, A., Mensah, A. A., Mohr, C., Nemitz, E., O’Dowd, C., Ovadnevaite, J., Pandis, S. N., Petäjä, T., Poulain, L., Saarikoski, S., Sellegri, K., Swietlicki, E., Tiitta, P., Worsnop, D. R., Baltensperger, U., and Prévôt, A. S. H.: Organic aerosol components derived from 25 AMS data sets across Europe using a consistent ME-2 based source apportionment approach, Atmos. Chem. Phys., 14(12), 6159-6176, doi:10.5194/acp-14-6159-2014, 2014.

Donahue, N. M., Robinson, A. L., Stanier, C. O., and Pandis, S. N.: Coupled Partitioning, Dilution, and Chemical Aging of Semivolatile Organics, Environ. Sci. Technol., 40, 2635-2643, doi:10.1021/es052297c, 2006

Donahue, N. M., Robinson, A. L., and Pandis, S. N.: Atmospheric organic particulate matter: From smoke to secondary organic aerosol, Atmos. Environ., 43, 94-106, doi:10.1016/j.atmosenv.2008.09.055, 2009.

Donahue, N. M., Epstein, S. A., Pandis, S. N., and Robinson, A. L.: A two-dimensional volatility basis set: 1. organic-aerosol mixing thermodynamics, Atmos. Chem. Phys., 11, 3303-3318, doi:10.5194/acp-11-3303-2011, 2011.

Draxler, R. and Rolph, G. D.: HYSPLIT (HYbrid Single-Particle Lagrangian Integrated Trajectory) Model access via NOAA ARL READY Website, NOAA Air Resour. Lab. Silver Spring, MD, available from: http://ready.arl.noaa.gov/HYSPLIT.php, 2013.

Ehn, M., Thornton, J. A., Kleist, E., Sipilä, M., Junninen, H., Pullinen, I., Springer, M., Rubach, F., Tillmann, R., Lee, B., LopezHilfiker, F., Andres, S., Acir, I.-H., Rissanen, M., Jokinen, T., Schobesberger, S., Kangasluoma, J., Kontkanen, J., Nieminen, T., Kurtén, T., Nielsen, L. B., Jørgensen, S., Kjaergaard, H. G., Canagaratna, M., Maso, M. D., Berndt, T., Petäjä, T., Wahner, A., Kerminen, V.-M., Kulmala, M., Worsnop, D. R., Wildt, J., and Mentel, T. F.: A large source of low-volatility secondary organic aerosol, Nature, 506, 476-479, doi:10.1038/nature13032, 2014.

Fuller, E. N., Schettler, P. D., and Giddings, J. C.: New method for prediction of binary gas-phase diffusion coefficients, Ind. Eng. Chem., 58, 18-27, doi:10.1021/ie50677a007, 1966.

Girolami, G. S.: A Simple "Back of the Envelope" Method for Estimating the Densities and Molecular Volumes of Liquids and Solids, J. Chem. Educ., 71, 962-964, doi:10.1021/ed071p962, 1994.

Hallquist, M., Wenger, J. C., Baltensperger, U., Rudich, Y., Simpson, D., Claeys, M., Dommen, J., Donahue, N. M., George, C., Goldstein, A. H., Hamilton, J. F., Herrmann, H., Hoffmann, T., Iinuma, Y., Jang, M., Jenkin, M. E., Jimenez, J. L., KiendlerScharr, A., Maenhaut, W., McFiggans, G., Mentel, T. F., Monod, A., Prévôt, A. S. H., Seinfeld, J. H., Surratt, J. D., Szmigielski, R., and Wildt, J.: The formation, properties and impact of secondary organic aerosol: current and emerging issues, Atmos. Chem. Phys., 9, 5155-5236, doi:10.5194/acp-9-5155-2009, 2009. 
Heald, C. L., Jacob, D. J., Park, R. J., Russell, L. M., Huebert, B. J., Seinfeld, J. H., Liao, H., and Weber, R. J.: A large organic aerosol source in the free troposphere missing from current models, Geophys. Res. Lett., 32, L18809, doi:10.1029/2005GL023831, 2005.

Hussein, T., Maso, M. D., Petäjä, T., Koponen, I. K., Paatero, P., Aalto, P. P., Hämeri, K., and Kulmala, M.: Evaluation of an automatic algorithm for fitting the particle number size distributions, Boreal Environ., 10, 337-355, 2005.

Jacobson, M. Z.: Fundamentals of atmospheric modeling, second edition, Cambridge University Press, New York, 528-529, 2005.

Jenkin, M. E.: Modelling the formation and composition of secondary organic aerosol from $\alpha$ - and $\beta$-pinene ozonolysis using MCM v3, Atmos. Chem. Phys., 4, 1741-1757, doi:10.5194/acp4-1741-2004, 2004.

Jenkin, M. E., Saunders, S. M., and Pilling, M. J.: The tropospheric degradation of volatile organic compounds: a protocol for mechanism development, Atmos. Environ., 31, 81-104, doi:10.1016/S1352-2310(96)00105-7, 1997.

Jimenez, J. L., Canagaratna, M. R., Donahue, N. M., Prevot, A. S. H., Zhang, Q., Kroll, J. H., DeCarlo, P. F., Allan, J. D., Coe, H., Ng, N. L., Aiken, A. C., Docherty, K. S., Ulbrich, I. M., Grieshop, A. P., Robinson, A. L., Duplissy, J., Smith, J. D., Wilson, K. R., Lanz, V. A., Hueglin, C., Sun, Y. L., Tian, J., Laaksonen, A., Raatikainen, T., Rautiainen, J., Vaattovaara, P., Ehn, M., Kulmala, M., Tomlinson, J. M., Collins, D. R., Cubison, M. J., Dunlea, E. J., Huffman, J. A., Onasch, T. B., Alfarra, M. R., Williams, P. I., Bower, K., Kondo, Y., Schneider, J., Drewnick, F., Borrmann, S., Weimer, S., Demerjian, K., Salcedo, D., Cottrell, L., Griffin, R., Takami, A., Miyoshi, T., Hatakeyama, S., Shimono, A., Sun, J. Y., Zhang, Y. M., Dzepina, K., Kimmel, J. R., Sueper, D., Jayne, J. T., Herndon, S. C., Trimborn, A. M., Williams, L. R., Wood, E. C., Middlebrook, A. M., Kolb, C. E., Baltensperger, U. and Worsnop, D. R.: Evolution of organic aerosols in the atmosphere, Science, 326, 1525-1529, doi:10.1126/science.1180353, 2009.

Kerminen, V.-M., Paramonov, M., Anttila, T., Riipinen, I., Fountoukis, C., Korhonen, H., Asmi, E., Laakso, L., Lihavainen, H., Swietlicki, E., Svenningsson, B., Asmi, A., Pandis, S. N., Kulmala, M. and Petäjä, T.: Cloud condensation nuclei production associated with atmospheric nucleation: a synthesis based on existing literature and new results, Atmos. Chem. Phys., 12, 12037-12059, doi:10.5194/acp-12-12037-2012, 2012.

Korhonen, H., Lehtinen, K. E. J., and Kulmala, M.: Multicomponent aerosol dynamics model UHMA: model development and validation, Atmos. Chem. Phys., 4, 757-771, doi:10.5194/acp-4757-2004, 2004.

Kroll, J. H. and Seinfeld, J. H.: Chemistry of secondary organic aerosol: Formation and evolution of low-volatility organics in the atmosphere, Atmos. Environ., 42, 3593-3624, doi:10.1016/j.atmosenv.2008.01.003, 2008.

Kroll, J. H., Smith, J. D., Che, D. L., Kessler, S. H., Worsnop, D. R., and Wilson, K. R.: Measurement of fragmentation and functionalization pathways in the heterogeneous oxidation of oxidized organic aerosol., Phys. Chem. Chem. Phys., 11, 8005-8014, doi:10.1039/b905289e, 2009.

Kroll, J. H., Donahue, N. M., Jimenez, J. L., Kessler, S. H., Canagaratna, M. R., Wilson, K. R., Altieri, K. E., Mazzoleni, L. R., Wozniak, A. S., Bluhm, H., Mysak, E. R., Smith, J. D., Kolb, C. E., and Worsnop, D. R.: Carbon oxidation state as a metric for describing the chemistry of atmospheric organic aerosol, Nat. Chem., 3, 133-139, doi:10.1038/nchem.948, 2011.

Lane, T. E., Donahue, N. M., and Pandis, S. N.: Simulating secondary organic aerosol formation using the volatility basis-set approach in a chemical transport model, Atmos. Environ., 42, 7439-7451, doi:10.1016/j.atmosenv.2008.06.026, 2008.

Lindfors, V., Rinne, J., and Laurila, T.: Upscaling the BIPHOREP Results - Regional Biogenic VOC Emissions in the European Boreal Zone, Eur. Comm., Brussels, 127-150, 1999.

Murphy, B. N. and Pandis, S. N.: Simulating the Formation of Semivolatile Primary and Secondary Organic Aerosol in a Regional Chemical Transport Model, Environ. Sci. Technol., 43, 4722-4728, doi:10.1021/es803168a, 2009.

Murphy, B. N., Donahue, N. M., Fountoukis, C., and Pandis, S. N.: Simulating the oxygen content of ambient organic aerosol with the 2D volatility basis set, Atmos. Chem. Phys., 11, 7859-7873, doi:10.5194/acp-11-7859-2011, 2011.

Murphy, B. N., Donahue, N. M., Fountoukis, C., Dall'Osto, M., O'Dowd, C., Kiendler-Scharr, A., and Pandis, S. N.: Functionalization and fragmentation during ambient organic aerosol aging: application of the 2-D volatility basis set to field studies, Atmos. Chem. Phys., 12, 10797-10816, doi:10.5194/acp-1210797-2012, 2012.

Nannoolal, Y., Rarey, J., and Ramjugernath, D.: Estimation of pure component properties, Fluid Phase Equilib., 269, 117-133, doi:10.1016/j.fluid.2008.04.020, 2008.

O’Dowd, C. D., Aalto, P., Hmeri, K., Kulmala, M., and Hoffmann, T.: Aerosol formation: atmospheric particles from organic vapours, Nature, 416, 497-498, doi:10.1038/416497a, 2002.

O’Dowd, C. D., Facchini, M. C., Cavalli, F., Ceburnis, D., Mircea, M., Decesari, S., Fuzzi, S., Yoon, Y. J., and Putaud, J.-P.: Biogenically driven organic contribution to marine aerosol., Nature, 431, 676-680, doi:10.1038/nature02959, 2004.

Odum, J. R., Hoffmann, T., Bowman, F., Collins, D., Flagan, R. C., and Seinfeld, J. H.: Gas/Particle Partitioning and Secondary Organic Aerosol Yields, Environ. Sci. Technol., 30, 2580-2585, doi:10.1021/es950943+, 1996.

Pankow, J. F. and Asher, W. E.: SIMPOL.1: a simple group contribution method for predicting vapor pressures and enthalpies of vaporization of multifunctional organic compounds, Atmos. Chem. Phys., 8, 2773-2796, doi:10.5194/acp-8-27732008, 2008.

Perraud, V., Bruns, E. a., Ezell, M. J., Johnson, S. N., Yu, Y., Alexander, M. L., Zelenyuk, A., Imre, D., Chang, W. L., Dabdub, D., Pankow, J. F., and Finlayson-Pitts, B. J.: Nonequilibrium atmospheric secondary organic aerosol formation and growth, Proc. Natl. Acad. Sci. USA, 109, 2836-2841, 2012.

Roldin, P., Swietlicki, E., Schurgers, G., Arneth, A., Lehtinen, K. E. J., Boy, M., and Kulmala, M.: Development and evaluation of the aerosol dynamics and gas phase chemistry model ADCHEM, Atmos. Chem. Phys., 11, 5867-5896, doi:10.5194/acp-11-58672011, 2011a.

Roldin, P., Swietlicki, E., Massling, A., Kristensson, A., Löndahl, J., Eriksson, A., Pagels, J., and Gustafsson, S.: Aerosol ageing in an urban plume - implication for climate, Atmos. Chem. Phys., 11, 5897-5915, doi:10.5194/acp-11-5897-2011, 2011 b.

Roldin, P., Eriksson, A. C., Nordin, E. Z., Hermansson, E., Mogensen, D., Rusanen, A., Boy, M., Swietlicki, E., Svenningsson, B., Zelenyuk, A., and Pagels, J.: Modelling non-equilibrium 
secondary organic aerosol formation and evaporation with the aerosol dynamics, gas- and particle-phase chemistry kinetic multilayer model ADCHAM, Atmos. Chem. Phys., 14, 7953-7993, doi:10.5194/acp-14-7953-2014, 2014.

Rolph, G. D.: NOAA Air Resource Laboratory Real-time Environmental Application and Display sYstem (READY) Website, available at: http://www.ready.noaa.gov, NOAA Air Resources Laboratory, Collage Park, MD, 2013.

Saunders, S. M., Jenkin, M. E., Derwent, R. G., and Pilling, M. J.: Protocol for the development of the Master Chemical Mechanism, MCM v3 (Part A): tropospheric degradation of nonaromatic volatile organic compounds, Atmos. Chem. Phys., 3, 161-180, doi:10.5194/acp-3-161-2003, 2003.

Scott, C. E., Rap, A., Spracklen, D. V., Forster, P. M., Carslaw, K. S., Mann, G. W., Pringle, K. J., Kivekäs, N., Kulmala, M., Lihavainen, H., and Tunved, P.: The direct and indirect radiative effects of biogenic secondary organic aerosol, Atmos. Chem. Phys., 14, 447-470, doi:10.5194/acp-14-447-2014, 2014.

Shrivastava, M., Zelenyuk, A., Imre, D., Easter, R., Beranek, J., Zaveri, R. A., and Fast, J.: Implications of low volatility SOA and gas-phase fragmentation reactions on SOA loadings and their spatial and temporal evolution in the atmosphere, J. Geophys. Res. Atmos., 118, 3328-3342, doi:10.1002/jgrd.50160, 2013.

Simpson, D., Benedictow, A., Berge, H., Bergström, R., Emberson, L. D., Fagerli, H., Flechard, C. R., Hayman, G. D., Gauss, M., Jonson, J. E., Jenkin, M. E., Nyíri, A., Richter, C., Semeena, V. S., Tsyro, S., Tuovinen, J.-P., Valdebenito, Á., and Wind, P.: The EMEP MSC-W chemical transport model - technical description, Atmos. Chem. Phys., 12, 7825-7865, doi:10.5194/acp-127825-2012, 2012.

Spracklen, D. V., Jimenez, J. L., Carslaw, K. S., Worsnop, D. R., Evans, M. J., Mann, G. W., Zhang, Q., Canagaratna, M. R., Allan, J., Coe, H., McFiggans, G., Rap, A., and Forster, P.: Aerosol mass spectrometer constraint on the global secondary organic aerosol budget, Atmos. Chem. Phys., 11, 12109-12136, doi:10.5194/acp-11-12109-2011, 2011.

Stohl, A.: Computation, accuracy and applications of trajectories-A review and bibliography, Atmos. Environ., 32, 947-966, 1998.
Tunved, P., Hansson, H.-C., Kerminen, V.-M., Ström, J., Maso, M. D., Lihavainen, H., Viisanen, Y., Aalto, P. P., Komppula, M. and Kulmala, M.: High natural aerosol loading over boreal forests, Science, 312, 261-263, doi:10.1126/science.1123052, 2006.

Väänänen, R., Kyrö, E.-M., Nieminen, T., Kivekäs, N., Junninen, H., Virkkula, A., Dal Maso, M., Lihavainen, H., Viisanen, Y., Svenningsson, B., Holst, T., Arneth, A., Aalto, P. P., Kulmala, M., and Kerminen, V.-M.: Analysis of particle size distribution changes between three measurement sites in northern Scandinavia, Atmos. Chem. Phys., 13, 11887-11903, doi:10.5194/acp13-11887-2013, 2013.

Valorso, R., Aumont, B., Camredon, M., Raventos-Duran, T., Mouchel-Vallon, C., Ng, N. L., Seinfeld, J. H., Lee-Taylor, J., and Madronich, S.: Explicit modelling of SOA formation from $\alpha$-pinene photooxidation: sensitivity to vapour pressure estimation, Atmos. Chem. Phys., 11, 6895-6910, doi:10.5194/acp-116895-2011, 2011.

Volkamer, R., Jimenez, J. L., San Martini, F., Dzepina, K., Zhang, Q., Salcedo, D., Molina, L. T., Worsnop, D. R., and Molina, M. J.: Secondary organic aerosol formation from anthropogenic air pollution: Rapid and higher than expected, Geophys. Res. Lett., 33, L17811, doi:10.1029/2006GL026899, 2006.

Wang, Z. B., Hu, M., Mogensen, D., Yue, D. L., Zheng, J., Zhang, R. Y., Liu, Y., Yuan, B., Li, X., Shao, M., Zhou, L., Wu, Z. J., Wiedensohler, A., and Boy, M.: The simulations of sulfuric acid concentration and new particle formation in an urban atmosphere in China, Atmos. Chem. Phys., 13, 11157-11167, doi:10.5194/acp-13-11157-2013, 2013.

Yttri, K. E., Simpson, D., Nøjgaard, J. K., Kristensen, K., Genberg, J., Stenström, K., Swietlicki, E., Hillamo, R., Aurela, M., Bauer, H., Offenberg, J. H., Jaoui, M., Dye, C., Eckhardt, S., Burkhart, J. F., Stohl, A., and Glasius, M.: Source apportionment of the summer time carbonaceous aerosol at Nordic rural background sites, Atmos. Chem. Phys., 11, 13339-13357, doi:10.5194/acp11-13339-2011, 2011. 